\title{
Some Overlooked Features of Tropical Atlantic Climate Leading to a New Niño-Like Phenomenon*
}

\author{
Yuko OKumura $^{+}$And Shang-PING XIE \\ International Pacific Research Center, University of Hawaii at Manoa, Honolulu, Hawaii
}

(Manuscript received 18 April 2005, in final form 16 February 2006)

\begin{abstract}
The Atlantic Niño, an equatorial zonal mode akin to the Pacific El Niño-Southern Oscillation (ENSO), is phase-locked to boreal summer when the equatorial easterly winds intensify and the thermocline shoals in the Gulf of Guinea. A suite of satellite and in situ observations reveals a new mode of tropical Atlantic variability that displays many characteristics of the zonal mode but instead peaks in November-December (ND). This new mode is found to be statistically independent from both the Atlantic Niño in the preceding summer and the Pacific ENSO. The origin of this ND zonal mode lies in an overlooked aspect of the seasonal cycle in the equatorial Atlantic.

In November the equatorial easterly winds intensify for the second time, increasing upwelling and lifting the thermocline in the Gulf of Guinea. An analysis of high-resolution climatological data shows that these dynamical changes induce a noticeable SST cooling in the central equatorial Atlantic. The shoaling thermocline and increased upwelling enhance the SST sensitivity to surface wind changes, reinvigorating equatorial ocean-atmosphere interaction. The resultant ocean-atmospheric anomalies are organized into patterns that give rise to positive mutual feedback as Bjerknes envisioned for the Pacific ENSO. This ND zonal mode significantly affects interannual rainfall variability in coastal Congo-Angola during its early rainy season. It tends to further evolve into a meridional mode in the following March-April, affecting precipitation in northeast Brazil. Thus it offers potential predictability for climate over the Atlantic sector in early boreal winter, a season for which local ocean-atmosphere variability was otherwise poorly understood.
\end{abstract}

\section{Introduction}

\section{a. Interannual variability}

Sea surface temperature (SST) variations over the tropical Atlantic exert significant climatic influences over the surrounding continents (Hastenrath and Greischar 1993; Enfield and Alfaro 1999; Folland et al. 2001; Giannini et al. 2003). Ocean-atmosphere interactions play an important role in organizing SST variations in space and time [see Xie and Carton (2004) for a recent review of tropical Atlantic variability (TAV)].

\footnotetext{
* International Pacific Research Center Contribution Number 391 and School of Ocean and Earth Science and Technology Contribution Number 6797.

+ Current affiliation: Climate and Global Dynamics Division, NCAR, Boulder, Colorado.
}

Corresponding author address: Dr. Yuko Okumura, Climate and Global Dynamics Division, NCAR, P.O. Box 3000, Boulder, CO 80307.

E-mail: yukoo@ucar.edu
There are two prominent modes of tropical Atlantic ocean-atmosphere interaction, each existing in a narrow seasonal window (cf. Fig. 16). The Atlantic Niño, an equatorial zonal mode akin to the Pacific El NiñoSouthern Oscillation (ENSO), is most pronounced in boreal summer (May-August), featuring maximum SST anomalies on the equator and associated changes in easterly trade winds (Philander 1986; Zebiak 1993; Carton and Huang 1994). The meridional mode, on the other hand, appears in boreal spring (February-April), characterized by an anomalous cross-equatorial SST gradient and meridional displacement of the marine intertropical convergence zone (ITCZ; Nobre and Shukla 1996; Ruiz-Barradas et al. 2000). Positive feedback between the ocean and atmosphere allows these modes of SST anomalies to persist in time. Seasonally changing background state influences the type and strength of air-sea interaction that prevails in each season.

Besides the local air-sea interaction, external forcing, most notably the Pacific ENSO, significantly influences SST variability in the tropical Atlantic through atmospheric teleconnections. The ENSO effect also displays strong seasonality because both ENSO and its influence 
on the atmospheric teleconnection are seasonally phase-locked. Following the mature phase of a Pacific warm event in November-January, a basinwide warming typically begins in the tropical North Atlantic, peaking from boreal spring to early summer (Enfield and Mayer 1997; Saravanan and Chang 2000). Rainfall and other atmospheric responses are most pronounced during November-January when ENSO peaks. The ENSO-induced SST changes trigger further air-sea interaction within the tropical Atlantic (Chiang et al. 2002; Huang et al. 2002).

Thus, local air-sea interaction, along with remote forcing, forms the basis for climate prediction over tropical Africa and South America (Hastenrath and Greischar 1993). While significant progress has been made over the recent decades in understanding TAV and its effect on continental climate from late boreal winter to summer, local ocean-atmosphere variability is poorly understood during the rest of the year. In this study, we reexamine the interannual variability in the equatorial Atlantic with focus on late fall to early winter, using satellite observations accumulated for the past two decades. We show that the seasonal cycle strongly affects coupled variability during this season. To this end, the rest of this section reviews the seasonal cycle of the equatorial Atlantic.

\section{b. Seasonal cycle}

The equatorial Atlantic displays a pronounced annual seasonal cycle despite the sun crossing the equator twice a year (Mitchell and Wallace 1992). The climatic asymmetry with respect to the equator-the northward-displaced ITCZ - is the ultimate cause of the equatorial annual cycle: surface winds are southerly year-round, strengthening once a year in boreal summer and weakening once a year in spring (Xie 1994). In March-April, the equatorial SST reaches the maximum value of $28^{\circ}-29^{\circ} \mathrm{C}$ and the ITCZ comes close to the equator, with easterly trade winds converging onto it from both hemispheres (Fig. 1a). As the West African summer monsoon commences in May-June, the ITCZ moves to the north and enhanced southeasterly winds cool the equatorial ocean rapidly through upwelling and evaporation. The cooling is strongest in the eastern basin because the thermocline is shallow there. The subsequent ocean-atmosphere interaction helps to spread the eastern cooling to the west by inducing easterly wind anomalies near the western edge of the cold tongue (Nigam and Chao 1996; Okumura and Xie 2004). After the cold tongue reaches its peak in JulyAugust (Fig. 1b), the equatorial ocean slowly warms up until March.

Ocean dynamics plays an important role in the sea-
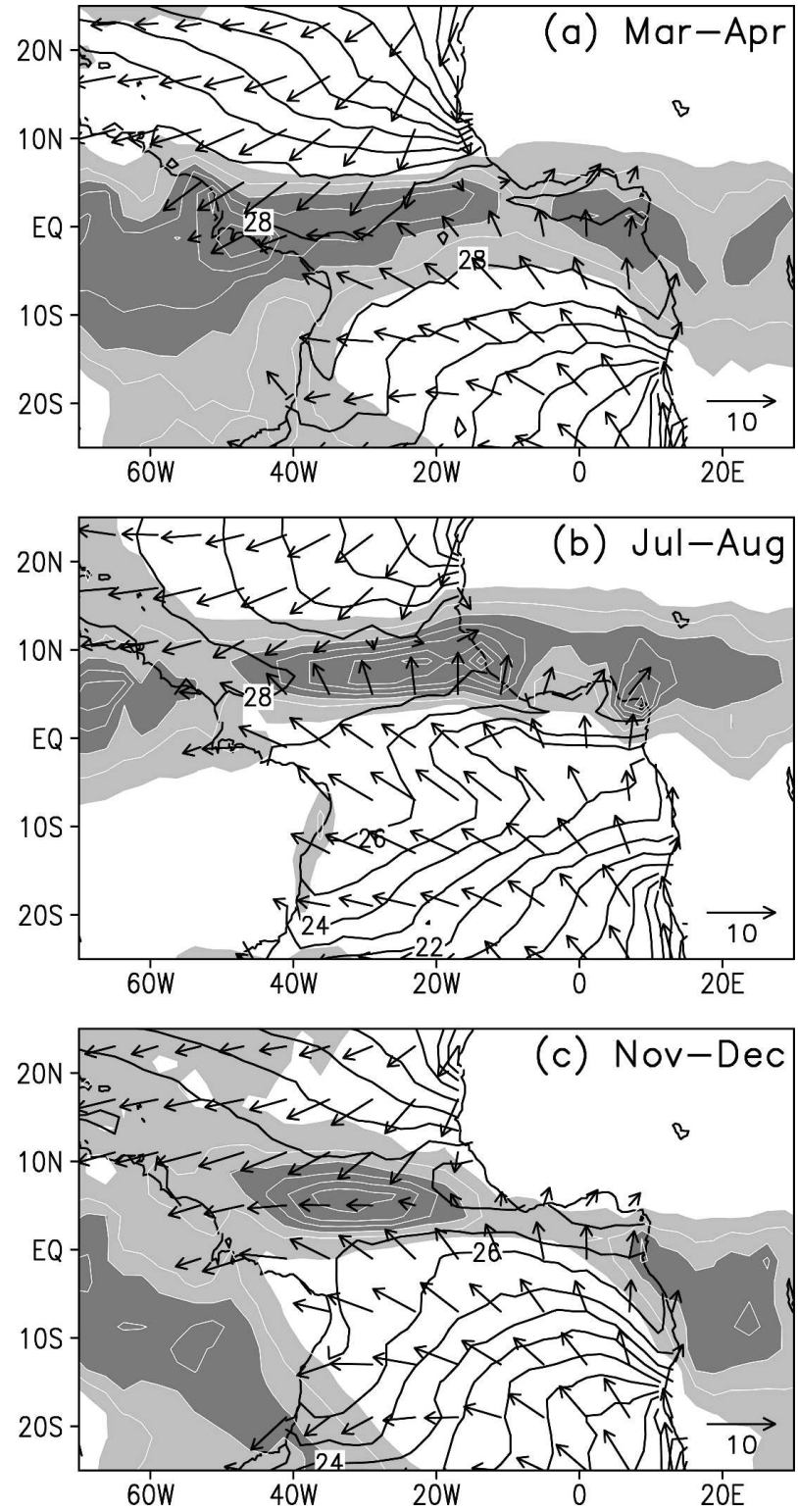

FIG. 1. Climatological distributions of the CMAP rainfall (light shade $>2 \mathrm{~mm} \mathrm{day}^{-1}$, dark shade $>6 \mathrm{~mm} \mathrm{day}^{-1}$ with white contours at intervals of $2 \mathrm{~mm} \mathrm{day}^{-1}$ ), COADS SST (black contours at intervals of $1^{\circ} \mathrm{C}$ ), and COADS surface wind velocity (vectors; $\mathrm{m} \mathrm{s}^{-1}$ ) for (a) Mar-Apr, (b) Jul-Aug, and (c) Nov-Dec.

sonal cycle of the equatorial Atlantic. In response to the summer easterly acceleration (Fig. 2a), the westward South Equatorial Current (SEC) accelerates (Richardson and McKee 1984; Fig. 2e), the equatorial upwelling increases (Helber et al. 2006), and the thermocline shoals in the eastern basin as much as $30-40 \mathrm{~m}$ (Houghton 1983; Weisberg and Colin 1986; Fig. 2c). [In the eastern equatorial Pacific, by contrast, the seasonal change in the thermocline depth is much smaller compared to the large interannual excursions associated 
(a) COADS U

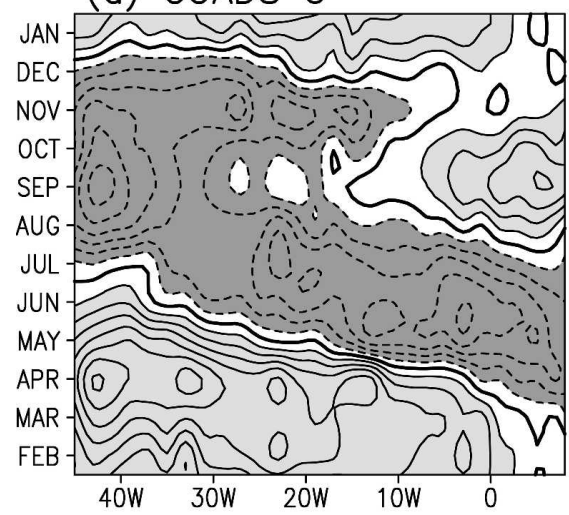

(c) $\mathrm{SSH}$

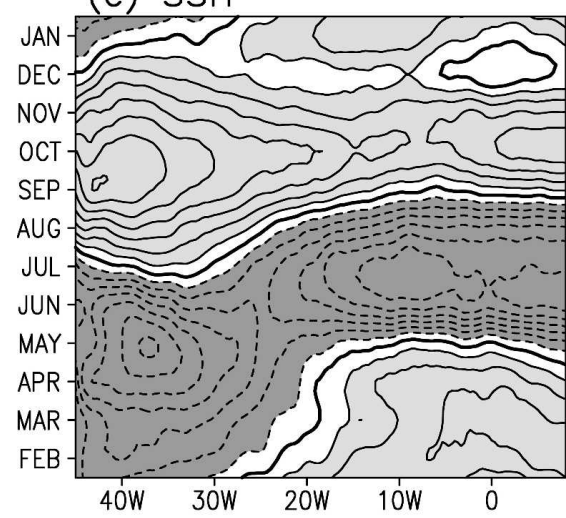

(e) Ship-drift U

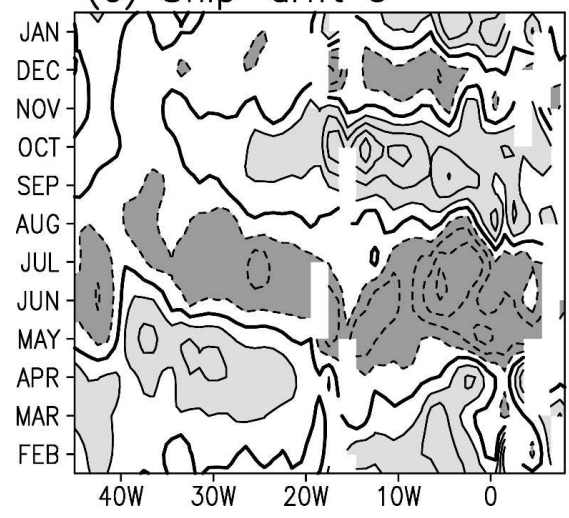

with ENSO (Xie 1994).] The thermocline shoaling reduces the subsurface temperature for upwelling and the accelerated SEC advects eastern cold water to the west, both contributing to the rapid summertime cooling. The summertime shoaling of the eastern thermocline is part of a basinwide adjustment to the strengthening easterly winds. Previous studies suggest that the large part of the seasonal upwelling in the Gulf of Guinea is remotely forced by the wind changes in the western equatorial Atlantic via equatorial Kelvin waves (Moore et al. 1978; Adamec and O'Brien 1978; McCreary et al. 1984; Busalacchi and Picaut 1983). (b) AVHRR SST

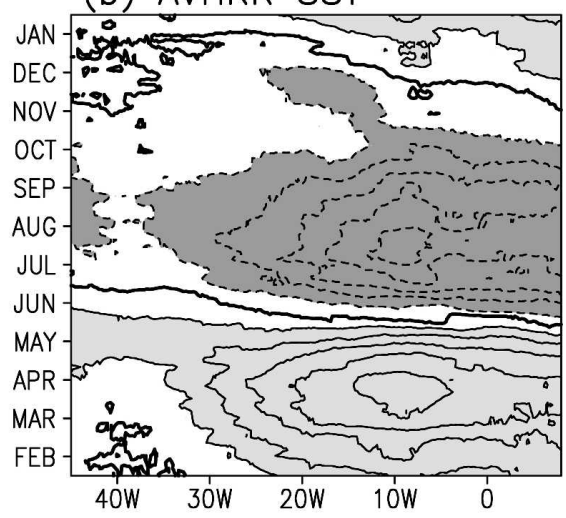

(d) COADS SST

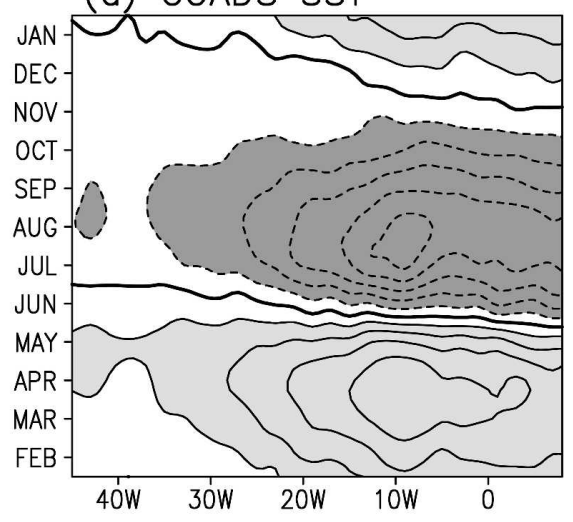

FIG. 2. Seasonal cycle of the equatorial Atlantic as represented by deviation form the annual mean $\left(1^{\circ} \mathrm{S}-1^{\circ} \mathrm{N}\right)$. (a) COADS surface zonal wind, (b) AVHRR SST, (c) $\mathrm{SSH}$, (d) COADS SST, and (e) ocean surface current. Contour intervals for wind, SST, SSH, and ocean current are 0.25 $\mathrm{m} \mathrm{s}^{-1}, 0.5^{\circ} \mathrm{C}, 1 \mathrm{~cm}$, and $10 \mathrm{~cm} \mathrm{~s}^{-1}$, respectively. Values greater (smaller) than the first positive (negative) contour are shaded with light (dark) gray. Zero counters are thickened. In this paper, a month label denotes the middle date of each month.

While the annual harmonic is dominant in the seasonal cycle of equatorial SST (Fig. 2d), easterly winds, ocean currents, upwellings, and thermocline depths all display a considerable semiannual cycle. During November-December (ND), the equatorial upwelling increases (Helber et al. 2006), the thermocline shoals in the Gulf of Guinea (Houghton 1983; Busalacchi and Picaut 1983; Fig. 2c), and the SEC accelerates (Richardson and McKee 1984; Fig. 2e) for the second time, apparently in response to a secondary acceleration of equatorial easterlies that peaks in November (Fig. 2a). Unlike the summer episode, neither the zonal wind nor 
the SEC displays distinct westward phase propagation, and their acceleration seems to occur simultaneously across the basin (Richardson and McKee 1984; Figs. $2 \mathrm{a}, \mathrm{e})$. The semiannual signal in dynamical fields is partly due to the resonant response of an oceanic basin mode to wind forcing (Philander and Pacanowski 1986; Weisberg and Tang 1990): part of the upwelling Kelvin (Rossby) waves forced by the summer acceleration (fall deceleration) of equatorial easterlies is reflected at the boundaries and eventually comes back to the eastern basin, reinforcing the shoaling by the November easterly acceleration. Associated with this ND thermocline shoaling, a secondary phytoplankton bloom is also observed in the eastern equatorial Atlantic (Monger et al. 1997). The modeling study by Jochum et al. (2004) suggests that the ND acceleration of SEC reenergizes tropical instability waves toward the end of the year.

To our knowledge, the effect of the November thermocline shoaling on equatorial SST has never been investigated. There have been several studies that report a secondary SST cooling along the coast of the Guinea Gulf later in the year, associated with the arrival of upwelling coastal Kelvin waves originating from the equator (e.g., Picaut 1983). Over the equatorial Atlantic basin, however, there is no apparent SST change associated with the November easterly acceleration in a widely used climatological dataset based on shipboard observations (Fig. 2d). In the following sections, we show that the November easterly acceleration does induce a noticeable SST cooling in the central equatorial Atlantic during ND and that this overlooked seasonal cooling reinvigorates the equatorial ocean-atmosphere interaction, leading to enhanced year-to-year coupled variability.

The present study examines the seasonal and interannual variations of the equatorial Atlantic during October-January, the part of the year for which few studies exist in the literature. The rest of this paper is organized as follows. Section 2 describes various datasets used in this study. Section 3 takes a close look at the seasonal cycle of the equatorial Atlantic with focus on the effect of the November easterly acceleration and thermocline shoaling on SST. Associated with these overlooked climatic features during ND, a new mode of TAV is reported in section 4. The climatic influence of this mode is also documented there. Section 5 discusses processes important for the seasonality of equatorial Atlantic variability and mechanisms for the November easterly acceleration. Section 6 is a summary.

\section{Data}

A suite of satellite/in situ observation and reanalysis datasets is used in this study. In analyses of the seasonal

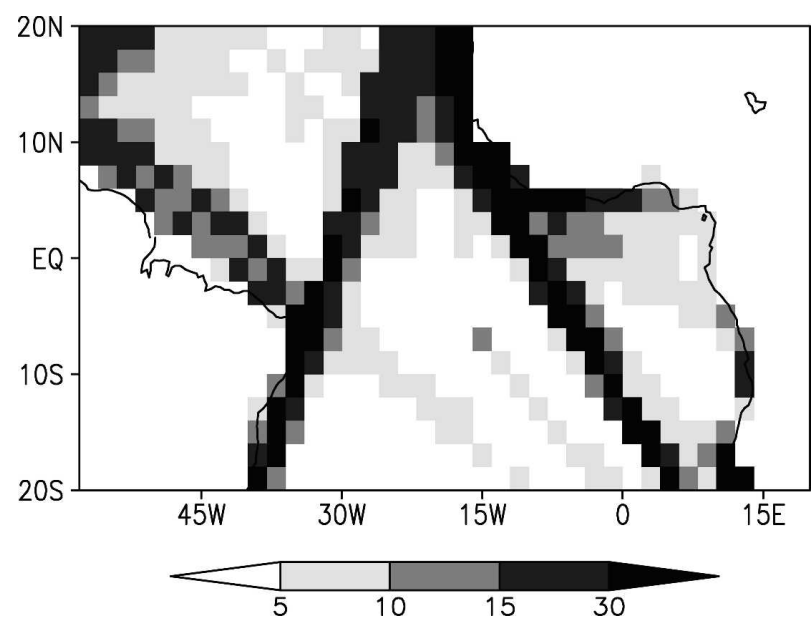

FIG. 3. Distribution in $2^{\circ}$ squares of the monthly COADS SST observations averaged during 1950-2002. The main ship routes are seen as dark bands, where more than 15 observations are made each month per $2^{\circ}$ square.

cycle, we examine a high-resolution SST climatology based on observations by the Advanced Very High Resolution Radiometer (AVHRR) on polar-orbiting satellites for 1985-99, available on a 9-km grid and 5-day intervals (Armstrong and Vazquez-Cuervo 2001). It is compared with monthly climatologies of SST and surface winds from the Comprehensive Ocean-Atmosphere Data Set (COADS; Woodruff et al. 1998) for 1950-2002, which is available on a $2^{\circ}$ grid and derived mainly from shipboard observations that are highly unevenly distributed in space (Fig. 3). As a proxy for thermocline depth, we use a monthly climatology of sea surface height ( $\mathrm{SSH}$ ) observed by satellite altimeters for November 1992-July 2004 on a $1 / 3^{\circ}$ grid (Ducet et al. 2000). A $1-\mathrm{cm}$ increase in SSH roughly corresponds to a 3-m deepening of the thermocline. An analysis of ocean surface currents uses a monthly climatology based on ship drift velocity observations mostly between 1920 and 1940 (Richardson and McKee 1984). An additional analysis is also conducted on pentad climatologies of surface wind, SST, and subsurface ocean temperature at $23^{\circ} \mathrm{W}$ on the equator for March 1999 December 2004, based on buoy observations from the Pilot Research Moored Array in the Tropical Atlantic (PIRATA; Servain et al. 1998).

For analyses of interannual SST variability, we use the monthly optimum interpolation of in situ and satellite SST product (OISST; Reynolds et al. 2002), which is available for December 1981-November 2004 on a $1^{\circ}$ grid. The inclusion of satellite data over this period turns out to be crucial to capturing the ND variability that is modest in amplitude and confined in latitude. The use of satellite-enhanced OISST limits our analysis 
to the recent $23 \mathrm{yr}$, a period that samples several cycles of interannual variability during $\mathrm{ND}$ on the equator (section 4).

Analyzed in conjunction with the SST field are monthly wind velocities at $1000 \mathrm{hPa}$ from the National Centers for Environmental Prediction (NCEP) and National Center for Atmospheric Research (NCAR) reanalysis (Kalnay et al. 1996), as well as precipitation from the monthly Climate Prediction Center (CPC) Merged Analysis of Precipitation (CMAP; Xie and Arkin 1996) that combines satellite and gauge observations. The former is available for January 1948November 2004 on a $2.5^{\circ}$ grid and the latter for January 1979-September 2004 on a $2.5^{\circ}$ grid. We also use the monthly SSH data described earlier and weekly SST observed by the Tropical Rain Measuring Mission (TRMM) satellite (Wentz et al. 2000; available for December 1997-November 2004 on a $1 / 4^{\circ}$ grid).

For each variable the monthly anomalies are calculated using the climatological monthly means over the available data period. (When more than one variable is analyzed at the same time, a common data period is used to calculate the climatologies.) Most of the interannual analyses are conducted using 2-month mean anomalies, which optimally suppress subseasonal fluctuations without averaging out variations tightly phaselocked to ND (cf. Fig. 12). The statistical significance of correlation analysis is verified based on the Student's $t$ test. The degree of freedom is estimated by dividing the record length by the typical peak-to-trough time scale of ND variability ( $\sim 2 \mathrm{yr}$ ). For 10 (5) degrees of freedom, a correlation coefficient greater than $0.58(0.75)$ is necessary to satisfy the $95 \%$ significance level.

\section{November-December cooling}

We begin with the seasonal cycle of the equatorial Atlantic. While COADS SST does not show significant changes in ND (Fig. 2d), the 15-yr mean pentad climatology of AVHRR data reveals an SST decrease of $0.5^{\circ} \mathrm{C}$ from November to early December in the central equatorial Atlantic (Fig. 2b) associated with the easterly wind acceleration and thermocline shoaling (Figs. $2 \mathrm{a}, \mathrm{c})$. It lasts only slightly more than a month and has its maximum amplitude in the central basin, away from the major shipping lanes where surface observations are concentrated (Fig. 3). In the ND cooling region $\left(2^{\circ} \mathrm{S}-\right.$ $\left.2^{\circ} \mathrm{N}, 14^{\circ}-22^{\circ} \mathrm{W}\right)$, the COADS SST observations are less than 5 times each month per $2^{\circ}$ square on average during 1950-2002. As a result, the ND cooling is poorly represented in Fig. 2d based on the COADS climatology.

This secondary cooling signal during ND is confined within a few degrees of the equator (not shown), suggesting the importance of equatorial ocean dynamics. The shoaling thermocline, increased upwelling, and accelerated westward SEC due to the enhanced easterly winds may all contribute to this ND decrease in SST over the central equatorial Atlantic. Zonal temperature advection by the SEC may be important west of $20^{\circ} \mathrm{W}$ where the westward temperature gradient is strong and varies in phase with the SEC (Foltz et al. 2003; Figs. $2 \mathrm{~b}, \mathrm{e})$. This process is consistent with the slight westward phase propagation signal of the secondary cooling (Fig. 2b). On the other hand, based on high-resolution ocean general circulation model (GCM) simulations, Peter et al. (2006) suggest that subsurface processes (upwelling, turbulent mixing, and entrainment) play a dominant role in the seasonal equatorial cooling. They show that cooling by subsurface processes peaks twice a year during June-August and ND, in agreement with the findings of this study. We note that the ND cooling peaks before the thermocline depth reaches the secondary minimum while the major summertime cooling peaks after the thermocline becomes shallowest (Figs. $2 b, c)$.

The ND cooling is also supported by PIRATA buoy observations (Fig. 4). At $23^{\circ} \mathrm{W}$ on the equator, the easterly winds strengthen from October to November and the thermocline shoals by $10 \mathrm{~m}$, attaining its secondary minimum near the end of December. ${ }^{1}$ On the western edge of the ND cooling region (Fig. 2b), SST at this site does not quite drop but remains constant for a prolonged period of 2 months, disrupting the slow warming trend that began in August and continues through April. The thermocline shoaling and the interruption of seasonal warming occur simultaneously, suggesting the significant effect of the secondary thermocline shoaling on equatorial SST. At $10^{\circ} \mathrm{W}$ on the equator, where another PIRATA buoy is deployed, the available data for 1999, 2000, and 2003 indicate that the ND thermocline shoaling is larger than that at $23^{\circ} \mathrm{W}$ (the data record is not long enough to construct robust climatologies and is therefore not shown for comparison). The ND cooling signal is, however, not very clear at this longitude, consistent with the AVHRR observations (Fig. 2b). At $10^{\circ} \mathrm{W}$, the easterly wind speed is less than half of that at $23^{\circ} \mathrm{W}$ during ND, and the resultant upwelling may not be strong enough to cool significantly the SST. Also, warm temperature advection by the enhanced SEC will

\footnotetext{
${ }^{1}$ At this buoy, the frequent disruptions in subsurface observations may distort the seasonal cycle and underestimate the secondary thermocline shoaling with a short data period of $6 \mathrm{yr}$. An examination of daily records shows that the ND thermocline shoaling amounts to $20 \mathrm{~m}$ or more in some years.
} 

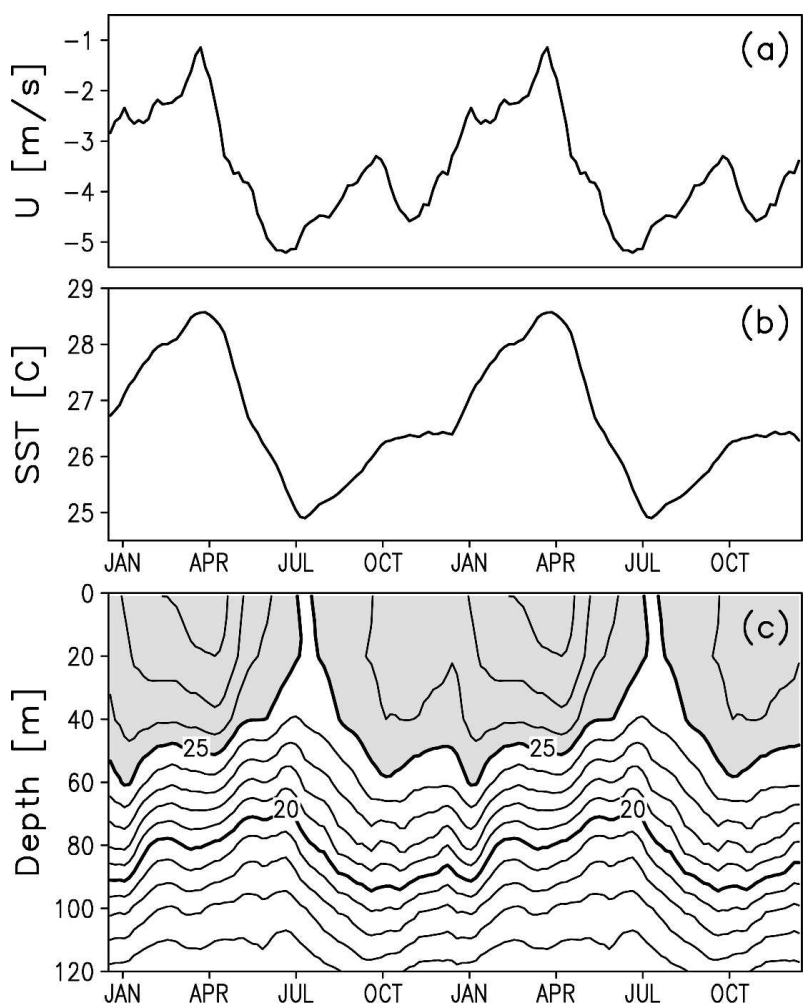

FIG. 4. Pentad climatology at $23^{\circ} \mathrm{W}$ on the equator based on the PIRATA buoy observation. (a) Zonal wind $\left(\mathrm{m} \mathrm{s}^{-1}\right)$ and (b) SST $\left({ }^{\circ} \mathrm{C}\right)$ as a function of time. (c) Time-depth section of ocean temperature (shade $>25^{\circ} \mathrm{C}$ with contours at $1{ }^{\circ} \mathrm{C}$ intervals). The calendar year is repeated and a 5-pentad running mean filter is applied to suppress subseasonal noises.

counteract the upwelling cooling in the presence of the eastward SST gradient east of $10^{\circ} \mathrm{W}$ (Fig. 1c).

The ND cooling displays considerable year-to-year variability in its magnitude. Figure 5 shows the longitude-time section of the weekly TRMM SST along the equator for two contrasting years. Toward the end of 2001 an extensive cooling took place between $5^{\circ}$ and $35^{\circ} \mathrm{W}$ that amounted to $1.5^{\circ} \mathrm{C}$. Lasting for two months, this ND cooling appears unrelated to quasi-monthly tropical instability waves, the SST signature of which peaks in boreal summer and begins to decay in fall (e.g., Hashizume et al. 2001). In the year 2003, by contrast, a secondary cooling signal was nearly absent. The cold water of SST below $26^{\circ} \mathrm{C}$ did not extend beyond $15^{\circ} \mathrm{W}$. The next section shows that this interannual variability in ND cooling is due to a zonal mode of air-sea interaction that involves Bjerknes (1969) feedback.

\section{Atlantic Niño II}

\section{a. Bjerknes feedback in the summer Atlantic Niño}

Interannual SST variability in the equatorial Atlantic displays distinct seasonality. Figure 6 shows monthly (a) 2001

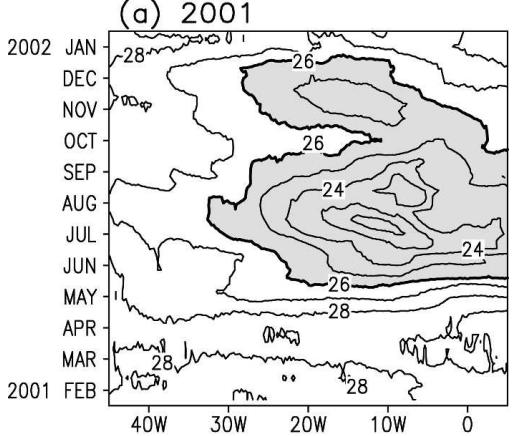

(b) 2003

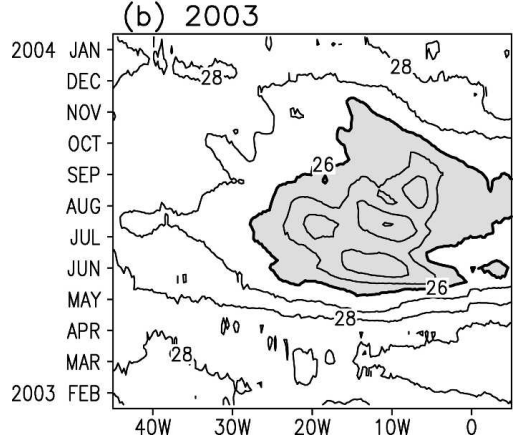

FIG. 5. Longitude-time sections of the TRMM SST along the equator $\left(1^{\circ} \mathrm{S}-1^{\circ} \mathrm{N}\right)$ for (a) Feb 2001-Jan 2002 and (b) Feb 2003Jan 2004. Contour intervals are $1{ }^{\circ} \mathrm{C}$ and values smaller than $26^{\circ} \mathrm{C}$ are shaded. A 3-week running mean filter is applied.

standard deviations of interannual SST variations along the equator and $10^{\circ} \mathrm{W}$ based on the OISST data. During May-July, the well-known summer Atlantic Niño causes large SST variance trapped near the equator in the eastern two-thirds of the basin, coincident with the major seasonal shoaling of the thermocline there (Fig. 2c).

Figure 7 shows June-July anomalies of SST, 1000$\mathrm{hPa}$ wind, and precipitation fields regressed onto the central equatorial Atlantic SST $\left(3^{\circ} \mathrm{S}-3^{\circ} \mathrm{N}, 5^{\circ}-15^{\circ} \mathrm{W}\right)$. In response to the eastern equatorial warming, easterly trades weaken to the west of the SST anomaly maximum. These anomalous westerly winds, in turn, reduce the equatorial upwelling and deepen the thermocline in the east, contributing to further equatorial warming. The corresponding cold events yield a similar positive feedback loop with anomalies of reversed signs. This so-called Bjerknes feedback organizes the equatorial ocean-atmosphere anomalies and is essential for the summer zonal mode. Compared to its Pacific counterpart, the Atlantic zonal mode is more tightly trapped on the equator and tends to vary in phase across the basin, reflecting the differences in the mean ocean-atmospheric conditions (Zebiak 1993).

A lag correlation analysis supports the idea that Bjerknes feedback sustains the equatorial ocean-atmo- 
(a) Equator

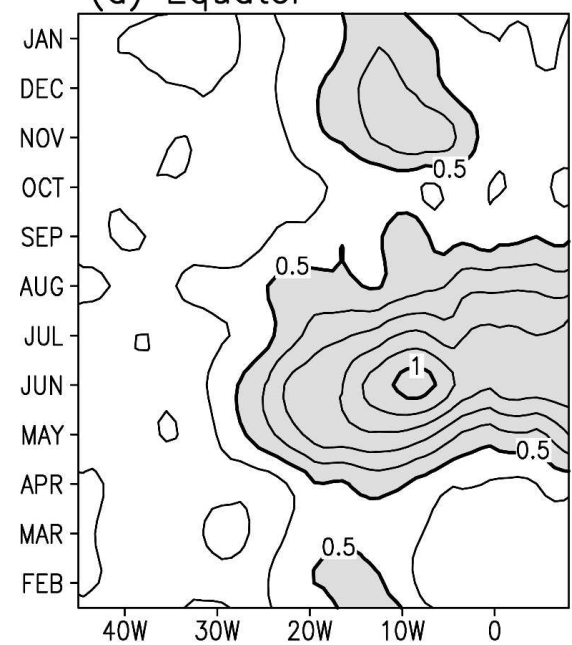

(b) $10 \mathrm{~W}$

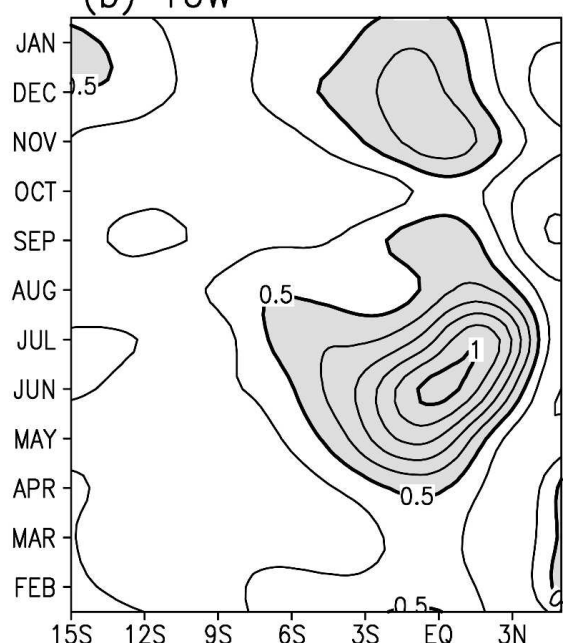

FIG. 6. Standard deviations of interannual OISST variability as a function of distance and calendar month along (a) the equator and (b) $10^{\circ} \mathrm{W}$. Contour intervals are $0.1^{\circ} \mathrm{C}$ and values grater than $0.5^{\circ} \mathrm{C}$ are shaded.

sphere anomalies in the summer Atlantic Niño (Fig. 8). June-July SST anomalies in the central equatorial Atlantic $\left(3^{\circ} \mathrm{S}-3^{\circ} \mathrm{N}, 5^{\circ}-15^{\circ} \mathrm{W}\right)$ are positively correlated with the local SSH (Fig. 8b) and the zonal wind in the western basin $\left(3^{\circ} \mathrm{S}-3^{\circ} \mathrm{N}, 25^{\circ}-35^{\circ} \mathrm{W}\right.$; Fig. $\left.8 \mathrm{c}\right)$ during both the previous and following months. The symmetric distribution of lag correlations indicates that SST and zonal wind anomalies are reinforcing each other, instead of exerting one-way forcing on the other. The

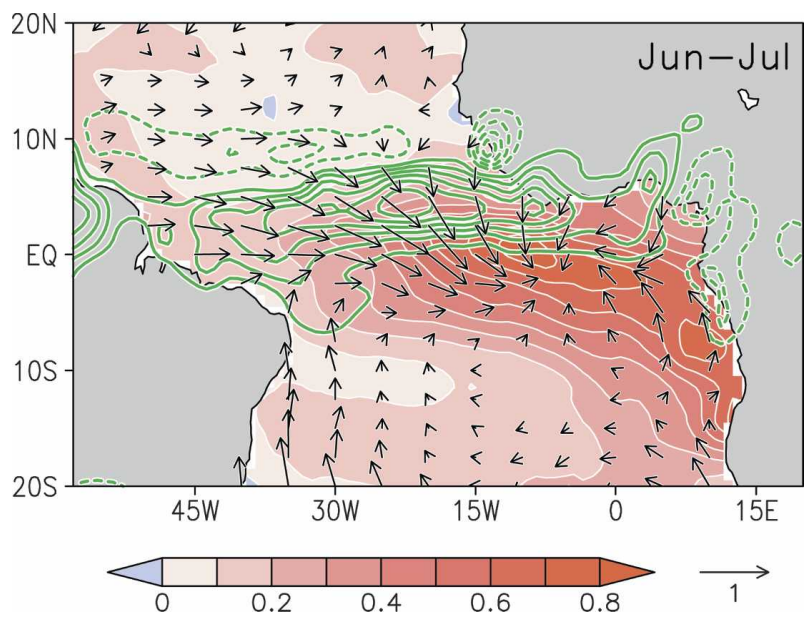

FIG. 7. Jun-Jul anomaly patterns associated with the summer Atlantic Niño. The OISST (color shade with white contours at intervals of $0.1^{\circ} \mathrm{C}$ ), NCEP-NCAR wind velocity at $1000 \mathrm{hPa}$ (vectors; $\mathrm{m} \mathrm{s}^{-1}$; masked over land), and CMAP precipitation (green contours at intervals of $0.3 \mathrm{~mm} \mathrm{day}^{-1}$; zero contours omitted and negative contours dashed) are regressed onto the central equatorial Atlantic SST $\left(3^{\circ} \mathrm{S}-3^{\circ} \mathrm{N}, 5^{\circ}-15^{\circ} \mathrm{W}\right)$.
SST-SSH correlation peak occurs when SSH leads SST by one month, a well-known characteristic of ENSO in the eastern Pacific. This SSH lead suggests the importance of ocean dynamics and the strong subsurface influence on SST.

\section{b. ND zonal mode}

During ND, the interannual SST variance reaches a secondary maximum in the central equatorial Atlantic, coincident with the easterly acceleration of wind and the secondary seasonal shoaling of the thermocline (Fig. 6). As in summer, the SST variations are equatorially trapped (Fig. 6b), suggesting that a common mechanism is at work with equatorial ocean dynamics playing a central role. This ND SST variance peak has not been documented previously. This subsection presents evidence that the ND variability is associated with a zonal mode of the equatorial ocean-atmosphere, which results in year-to-year variations in the ND seasonal cooling (Fig. 5) as the summer zonal mode involves significant modulations in the seasonal cold tongue.

Hereafter, we call an anomalous warm event in ND the Atlantic Niño II, to distinguish it from its summertime big brother. Unlike their summer counterparts, neither the seasonal ND cooling nor its interannual variance extends all the way to the African coast (Figs. $2 \mathrm{~b}, 6 \mathrm{a})$, possibly limited by weak mean upwelling east of the Greenwich meridian where the mean zonal wind is westerly during this time of the year (Fig. 1c). The Atlantic Niño II's amplitude in SST amounts to $65 \%$ of that of the summer Atlantic Niño (Fig. 6). 

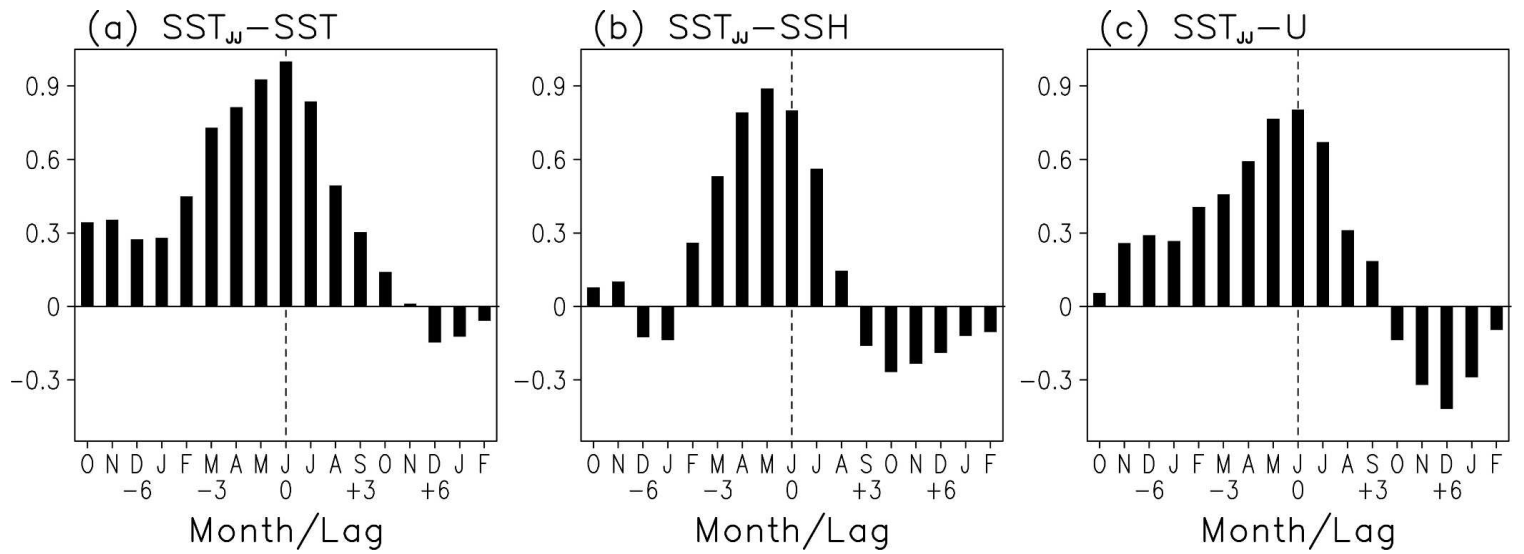

FIG. 8. Lag correlations between Jun-Jul OISST anomaly in the central equatorial Atlantic $\left(3^{\circ} \mathrm{S}-3^{\circ} \mathrm{N}, 5^{\circ}-15^{\circ} \mathrm{W}\right)$ and three indices in the previous and following months: (a) OISST and (b) SSH in the same region, and (c) NCEP-NCAR 1000-hPa zonal wind in the western equatorial Atlantic $\left(3^{\circ} \mathrm{S}-3^{\circ} \mathrm{N}, 25^{\circ}-35^{\circ} \mathrm{W}\right)$. The analysis period is (a), (c) Dec 1981-Nov 2004 and (b) Nov 1992-Jul 2004. Correlations are calculated using 2-month means, with the first month denoted on the abscissa.

We define an Atlantic Niño II index to be the ND SST anomaly averaged over the central equatorial Atlantic $\left(3^{\circ} \mathrm{S}-3^{\circ} \mathrm{N}, 5^{\circ}-15^{\circ} \mathrm{W}\right)$. Since 1982 , there are four warm events $(1987,1993,1997$, and 2003) and four cold events (1986, 1991, 1996, and 2001) that exceed one standard deviation for ND (Fig. 9). Figure 10a shows ND anomalies of SST, 1000-hPa wind, and precipitation fields regressed upon this index. The anomaly patterns bear a striking resemblance to those of the summer Atlantic Niño (Zebiak 1993; Carton and Huang 1994; Fig. 7). In the equatorial zone, oceanic warming is associated with an increase in precipitation and relaxed easterly trades. As in summer, the precipitation anomalies lie north of the SST anomalies, reflecting the latitude of the mean ITCZ (Fig. 1c). In response to the weakened easterlies, the thermocline deepens in the eastern equatorial Atlantic as observed by satellite al- timeters (Fig. 10b), which helps to amplify the equatorial SST warming. [Slight differences in SST and surface wind between Figs. 10a and 10b result from the different analysis periods, 1982-2003 and 1992-2003, respectively.] These observations, from independent sources, suggest that Bjerknes feedback is at work in the generation of the Atlantic Niño II.

Lag correlations of SST with SSH and zonal wind again support equatorial ocean-atmosphere interaction during ND (Figs. 11b,c). The SST-zonal wind correlation is nearly symmetric about lag zero, at which the correlation exceeds 0.6 , a value significant at the 95\% level and comparable to that for the Pacific ENSO (Zebiak 1993). The Atlantic Niño II is moderate in amplitude, but this result shows that the atmosphere is quite sensitive to small changes in equatorial SST. The SST-SSH correlation peak occurs with no lag but tends

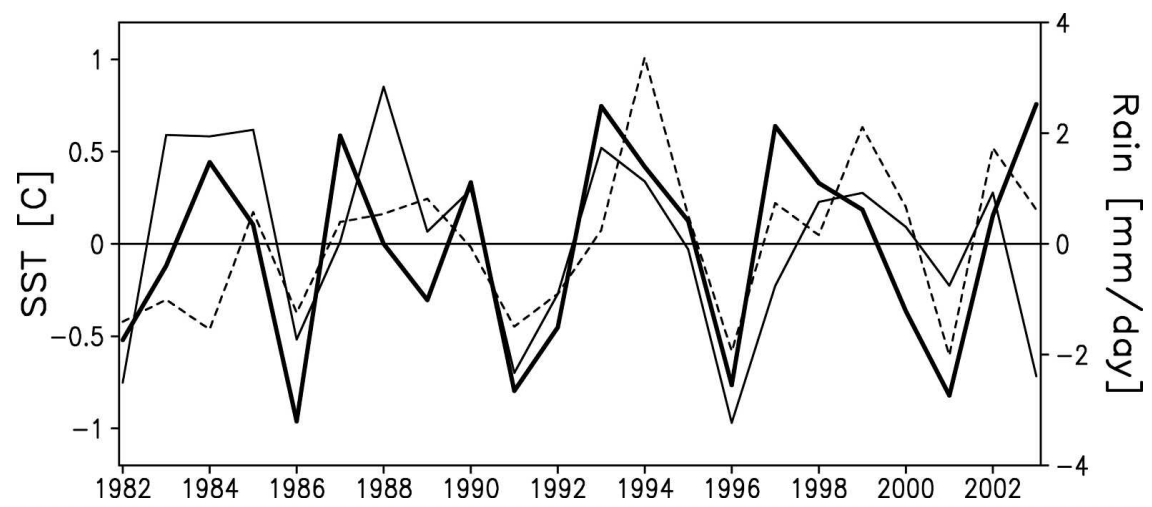

FIG. 9. Time series of the Atlantic Niño II index $\left({ }^{\circ} \mathrm{C}\right.$; thick solid), ND CMAP precipitation anomaly in coastal Congo-Angola $\left(2.5^{\circ}-12.5^{\circ} \mathrm{S}, 10^{\circ}-17.5^{\circ} \mathrm{E} ; \mathrm{mm} \mathrm{day}^{-1}\right.$; dashed), and meridional mode index $\left({ }^{\circ} \mathrm{C}\right.$; thin solid) defined as the difference in zonal-mean OISST between $10^{\circ}-20^{\circ} \mathrm{N}$ and $5^{\circ}-15^{\circ} \mathrm{S}$ (positive with a warmer South Atlantic) in the following Mar-Apr. 

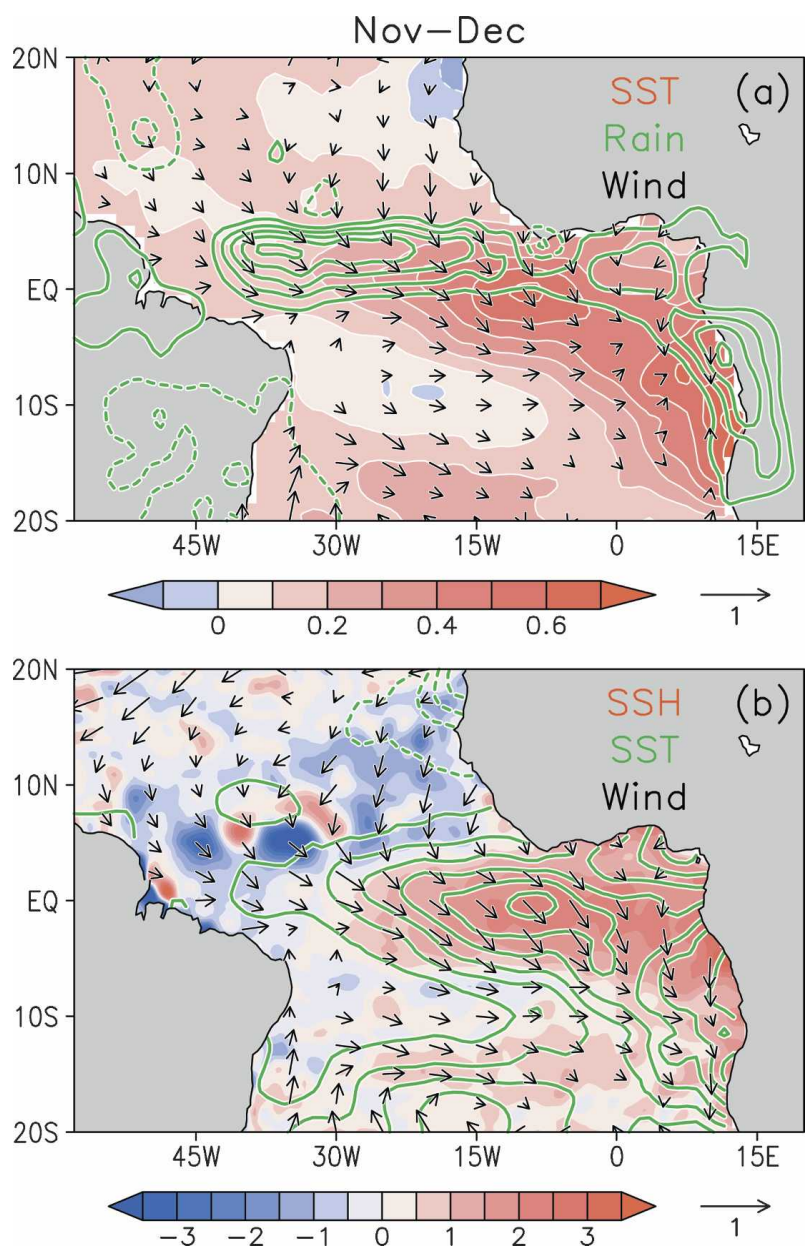

FIG. 10. (a) Same as in Fig. 7, but for ND anomalies regressed onto the Atlantic Niño II index. (b) Same as in (a), but for SSH (cm; color shade), NCEP-NCAR wind velocity at $1000 \mathrm{hPa}$ (vectors; $\left.\mathrm{m} \mathrm{s}^{-1}\right)$, and OISST $\left({ }^{\circ} \mathrm{C}\right.$; green contours at intervals of $0.1^{\circ} \mathrm{C}$; zero contours omitted and negative contours dashed). The analysis period is (a) 1982-2003 and (b) 1992-2003. to be larger when SSH leads. (If a 3-month running mean filter is applied instead of a 2-month, the SSTSSH correlation indeed peaks with SSH leading by 1 month.) The Atlantic Niño II is pronounced for a short period compared to ENSO and summer Atlantic Niño (Fig. 6), and the mean state changes rapidly during ND (Fig. 2), making it difficult to determine the phase difference between SST and SSH.

The Atlantic Niño II dominates ND SST variability in the tropical Atlantic. When the ND OISST field equatorward of $15^{\circ} \mathrm{S}-15^{\circ} \mathrm{N}$ is analyzed, the first empirical orthogonal function (EOF) mode resembles closely the anomaly pattern in Fig. 10, explaining $52 \%$ of the total SST variance (not shown). Compared to the leading EOF mode of June-July SST, which is similar to Fig. 7 and explains $56 \%$ of the total variance, equatorial SST anomalies in ND are more confined longitudinally near $10^{\circ} \mathrm{W}$.

The Atlantic Niño II is generally not a simple extension of the interannual events during summer (Fig. 12). In some years (1986, 1987, 2001, and 2003), the ND events appear to be a recurrence of the anomalies that develop in the previous summer and decay in early fall. In other years (1991, 1993, 1996, and 1997), the SST anomaly signs are reversed from the previous summer to fall, developing into the ND events. As a result, the correlation between the Atlantic Niño II index and previous June-July SST in the central equatorial Atlantic is nearly zero (Fig. 11a). The Atlantic Niño II index is also not significantly correlated with ENSO events in the Pacific, although they tend to peak around the same time (November-January; correlation $<0.1$ ).

We note that the ND SST variance peak seen in Fig. 6 is not evident in some reconstructed SST products. The EOFs used for interpolation in these products may
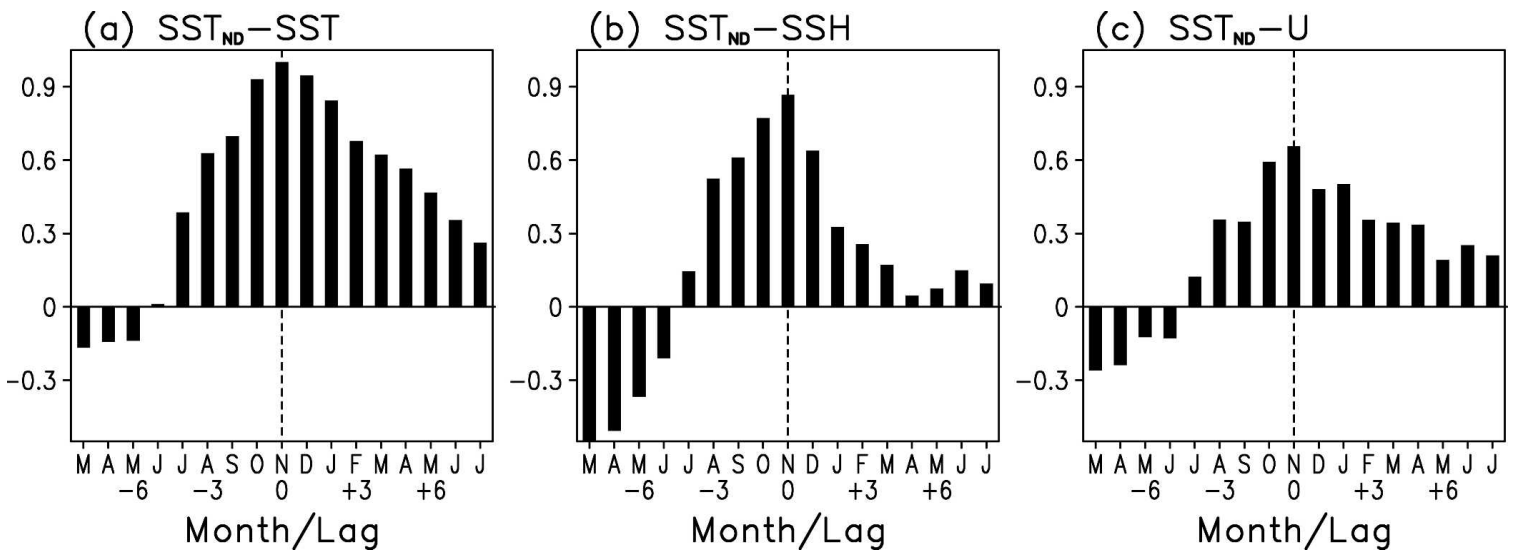

FIG. 11. Same as in Fig. 8, but the Atlantic Niño II index is correlated with (a) SST, (b) SSH, and (c) zonal wind in the previous and following months. 

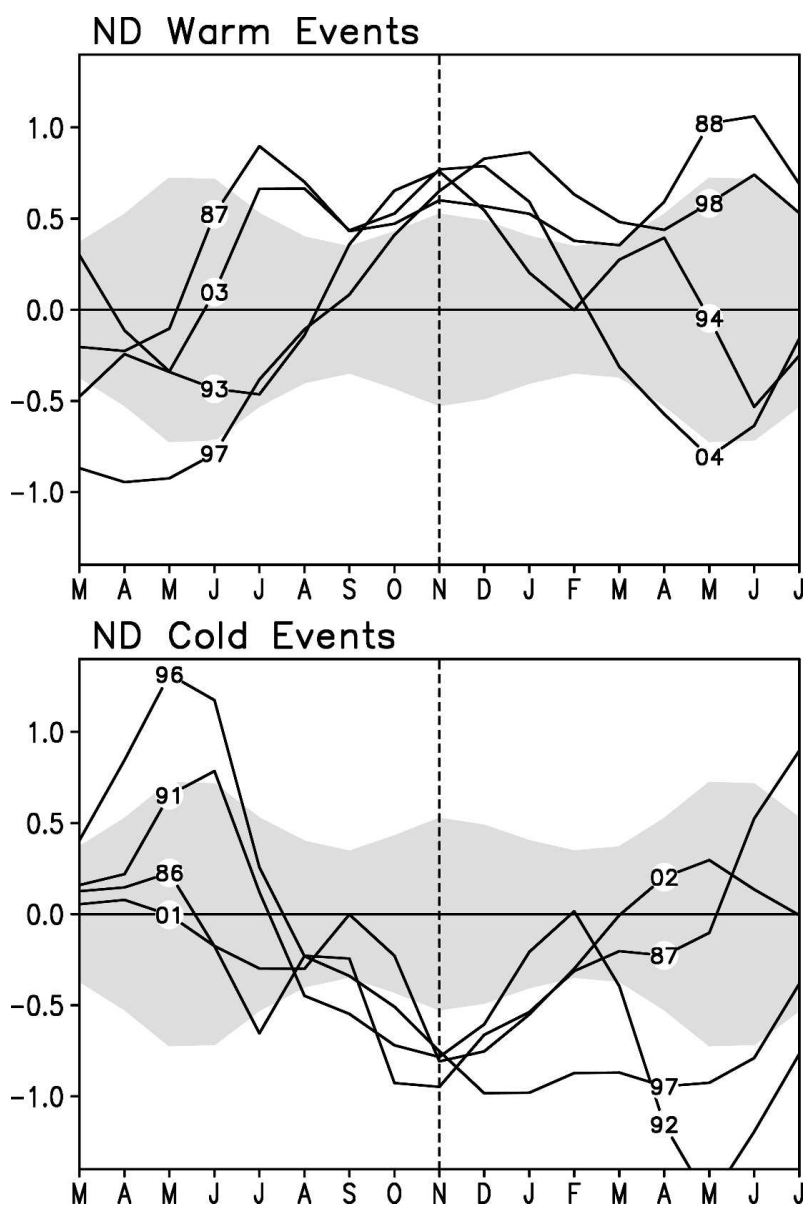

FIG. 12. Time series of OISST anomalies in the central equatorial Atlantic $\left(3^{\circ} \mathrm{S}-3^{\circ} \mathrm{N}, 5^{\circ}-15^{\circ} \mathrm{W}\right)$ for (top) warm $(1987,1993$, 1997, and 2003) and (bottom) cold (1986, 1991, 1996, and 2001) events in ND. The gray shading represents the range of one standard deviation. The SST anomaly and standard deviation are calculated using 2-month means, with the first month denoted on the abscissa.

underestimate the equatorially trapped variability. In addition, prior to 1980 , the ND peak is hardly distinguishable from the decaying signal of the summer Atlantic Niño, presumably due to insufficient observations, a long-term climate change, or both.

\section{c. Impact beyond the equatorial Atlantic}

The impact of the Atlantic Niño II extends beyond the equatorial Atlantic. Notable SST anomalies are found off the west coast of southern Africa due to the coastal Kelvin waves propagating from the equator (Fig. 10). While the coastal Kelvin wave signals in SSH attenuate away from the equator, SST anomalies are amplified off Angola, an active upwelling region with a shallow thermocline that is often called the Angola Dome (Yamagata and Iizuka 1995). The interannual

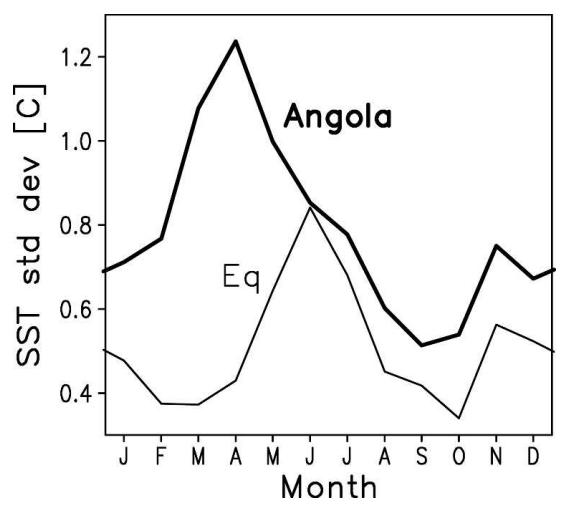

FIG. 13. Monthly standard deviation of interannual OISST variability $\left({ }^{\circ} \mathrm{C}\right)$ off Angola $\left(10^{\circ}-20^{\circ} \mathrm{S}, 8^{\circ} \mathrm{E}\right.$-coast; thick line $)$ and in the central equatorial Atlantic $\left(3^{\circ} \mathrm{S}-3^{\circ} \mathrm{N}, 5^{\circ}-15^{\circ} \mathrm{W}\right.$; thin line).

SST variance in this region shows a secondary maximum during November (Fig. 13), in addition to the well-known major peak in March-April associated with the Benguela Niño (Shannon et al. 1986; Florenchie et al. 2004). The Atlantic Niño II and accompanying coastal Kelvin wave propagation are responsible for this secondary peak, with the Niño II index being significantly correlated (0.79) with ND coastal SST $\left(10^{\circ}-\right.$ $20^{\circ} \mathrm{S}, 8^{\circ} \mathrm{E}$-coast). Its relation to the Benguela Niño in the following spring is not clear, however, as the coastal SST during ND does not significantly correlate with that in the following March-April.

Associated with the coastal SST anomalies during Atlantic Niño II events, precipitation increases near the coast of Congo-Angola (Fig. 10a). The simultaneous correlation coefficient between the Atlantic Niño II index and coastal Congo-Angola rainfall in ND $\left(2.5^{\circ}-\right.$ $\left.12.5^{\circ} \mathrm{S}, 10^{\circ}-17.5^{\circ} \mathrm{E}\right)$ is 0.59 , statistically significant at the 95\% level (Fig. 9). This region receives most of its annual rainfall from October to May, with two peaks in November and March when the continental rainband marches across the region following the sun (Figs. 1a,c). It is plausible that the coastal precipitation becomes sensitive to the Kelvin wave-induced SST anomalies during early austral summer. [We note that the rainfall in the same coastal region tends to decrease during the summer Atlantic Niño (Fig. 7). In summer, the seasonal mean ITCZ is displaced farther to the north (Fig. 1b) and may cause a difference in the anomalous moisture convergence.] Between warm and cold events, the ND accumulated rainfall changes by up to $120 \mathrm{~mm}$ as opposed to a climatological mean of $350 \mathrm{~mm}$ in coastal Congo-Angola. Previous studies of interannual rainfall variability in this region focus on the late rainy season in March-April (Hirst and Hastenrath 1983; Nicholson and Entekhabi 1987; Rouault et al. 2003) when coastal SST variations are most pronounced (Florenchie et al. 

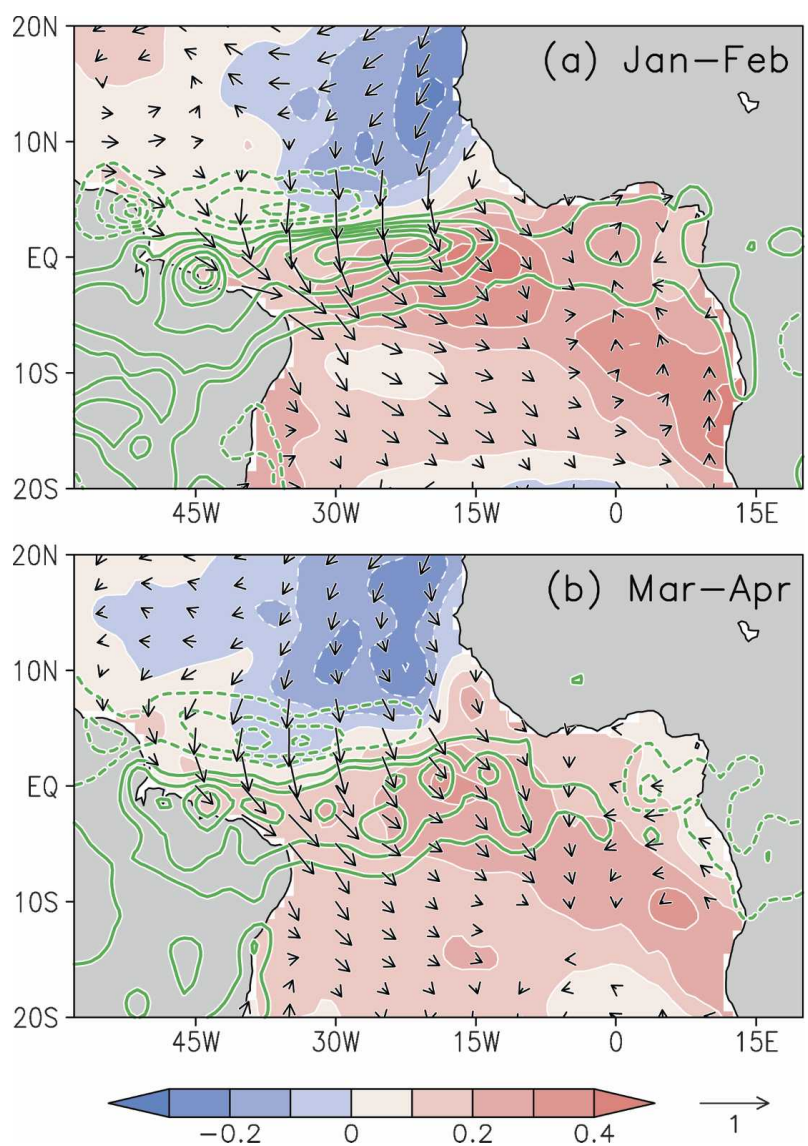

FIG. 14. Same as in Fig. 10a, but (a) Jan-Feb and (b) Mar-Apr fields regressed onto the Atlantic Niño II index.

2004; Fig. 13). Our results point to the Atlantic Niño II as a potential source of predictability for the coastal Congo-Angola precipitation during the early rainy season (ND).

\section{d. Evolution in the following season}

Atlantic Niño II's influence persists into subsequent months (Fig. 11a). In January-February, the negative SST anomaly off the West African coast in Fig. 10 starts to expand westward and covers the eastern half of the tropical North Atlantic (Fig. 14a). The positive SST anomaly weakens on the equator while spreading southward. By March-April, a north-south dipole pattern is formed in SST (Fig. 14b), reminiscent of the Atlantic meridional mode that is most pronounced during this time of the year (Nobre and Shukla 1996; RuizBarradas et al. 2000). Indeed, the Atlantic Niño II index is positively correlated with the meridional mode index in March-April (correlation =0.49; Fig. 9). [The anomalous interhemispheric SST gradient is largely attributed to the SST change in the tropical South Atlan- tic, but the Atlantic Niño II index is negatively correlated with the SST off West Africa (correlation $<-0.3)$.] With SST anomalies evolving in spatial structure, precipitation anomalies change from an equatorial monopole to a meridional dipole pattern, with a rainfall increase over northeast Brazil. Anomalous northerly winds blow from the colder to the warmer lobe of the SST dipole, deflected westward (eastward) north (south) of the equator by the Coriolis force to strengthen (weaken) the trade winds in the western basin. In January-February, these enhanced northeasterly trades in the tropical North Atlantic are related to a high pressure anomaly centered at $40^{\circ} \mathrm{N}$ and a low pressure anomaly over western Europe (not shown). The resultant wind-induced changes in surface latent heat flux act to reinforce the SST dipole. This sequence of air-sea interaction constitutes a positive feedback that helps sustain the meridional mode (Chang et al. 1997; Okumura et al. 2001).

The node of the March-April SST dipole is not exactly on the equator but displaced to the north near the annual-mean latitude of the ITCZ. Thus, equatorial SST anomalies project on both the zonal and meridional modes. Developing at the end of the year, Atlantic Niño II apparently further triggers the meridional mode in the following spring as the mean state becomes more symmetrical about the equator and favorable for the meridional mode (Okajima et al. 2003). The numerical experiments by Barreiro et al. (2004) support the idea that the tropical South Atlantic SST anomalies can invoke a feedback that generates SST anomalies in the tropical North Atlantic, enhancing the anomalous cross-equatorial SST gradient. This seasonal evolution from boreal winter to spring may partly explain the significant correlation between the zonal and meridional modes reported previously by Servain et al. (1999) although the Atlantic Niño II was likely to be smoothed out by a 6-month running mean filter they used.

The link between Atlantic Niño II and meridional mode can be useful information for seasonal prediction. At the southernmost latitude of the annual ITCZ excursion, springtime rainfall in northeast Brazil is strongly influenced by the meridional mode and associated north-south shift of the ITCZ (e.g., Hastenrath and Heller 1977; Moura and Shukla 1981). Using multiple regression models, some studies report that large part of the springtime rainfall variations there can be predicted from the Atlantic ocean-atmosphere conditions through the previous January (Hastenrath and Greischar 1993; Folland et al. 2001). By including the Atlantic Niño II index as a predictor in these models, the predictability can be significantly improved (Okumura 2005). 
(a) SST-SSH

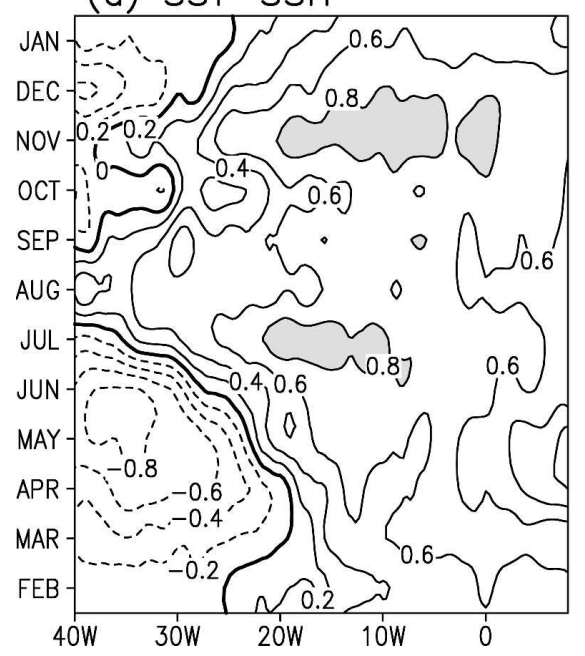

(b) $S S T-U$

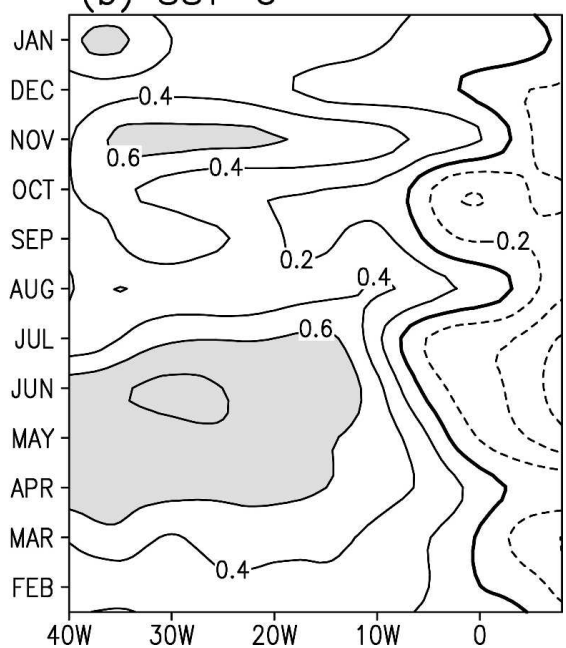

FIG. 15. Correlation coefficients of (a) SSH and (b) NCEP-NCAR zonal wind at $1000 \mathrm{hPa}$ with the central equatorial Atlantic OISST $\left(3^{\circ} \mathrm{S}-3^{\circ} \mathrm{N}, 5^{\circ}-15^{\circ} \mathrm{W}\right)$ as a function of longitude and month along the equator $\left(3^{\circ} \mathrm{S}-3^{\circ} \mathrm{N}\right)$. The analysis period is (a) Nov 1992-Jul 2004 and (b) Dec 1981-Nov 2004. Contour intervals are 0.2 and values greater than (a) 0.8 and (b) 0.6 are shaded.

\section{Discussion}

\section{a. Seasonality of Bjerknes feedback}

The seasonally varying ocean-atmospheric state causes the zonal mode to be phase-locked to boreal summer and ND, seasons when the enhanced equatorial easterly winds increase the upwelling and raise the thermocline in the east (Figs. 2a,c). For a given wind change during these seasons, the resultant changes in upwelling and thermocline depth lead to large variations in cold water advection into the surface mixed layer. Thus, the equatorial SST becomes sensitive to surface wind changes and the Bjerknes feedback strengthens as the mean thermocline shoals and the mean upwelling increases. [Chang et al. (2006) suggest that anomalous upwelling acting on the mean vertical temperature gradient (i.e., the mean thermocline depth) plays a more important role than mean upwelling acting on the anomalous vertical temperature gradient in driving equatorial Atlantic variability.]

Figure 15 displays monthly stratified correlations of the central equatorial SST with SSH and zonal wind along the equator. In boreal summer and early winter when the thermocline shoals, the SST variations in the central basin are significantly correlated with the local thermocline depth and the zonal wind in the western basin, with coefficients exceeding 0.8 and 0.6 , respectively. Note that the latter correlation is obtained for a 2-times-longer analysis period and both are significant at the $95 \%$ level. Similar results have been recently obtained by Keenlyside and Latif (2006). In boreal fall, on the other hand, the deepening thermocline appears to weaken the Bjerknes feedback and, hence, the correlation between the summer and ND zonal modes (Figs. 11a, 12). In fact, the summer SST anomalies and their interactions with the subsurface ocean/atmosphere decay rather rapidly by early fall, as revealed by the lag correlation analyses (Fig. 8).

These results suggest that the seasonal cycle in the thermocline depth influences the seasonality of Bjerknes feedback, phase-locking the zonal mode to boreal summer and ND in the equatorial Atlantic. Although the thermocline is only slightly shallower than its annual-mean level in ND (Fig. 2c), its depth is comparable to that in the central/eastern equatorial Pacific, a region of active thermocline feedback on SST. This conclusion is also consistent with coupled GCM studies in which a shallow thermocline is favorable for an intense Pacific ENSO (Meehl et al. 2001). The strong seasonality of the Bjerknes feedback calls for analysis to be stratified in seasons.

Beside the thermocline depth, there are several other factors that may influence the seasonality of Bjerknes feedback. While the SST-SSH correlation peaks in July (Fig. 15a), when the mean thermocline is shallowest (Fig. 2c), the SST-zonal wind correlation strengthens in April-June (Fig. 15b), somewhat earlier than the peak season of summer Atlantic Niño (May-July; Fig. 6). These properties suggest that the seasonal-mean SST and atmospheric convection are also important: equa- 
torial SST becomes too cool in July-August for atmospheric deep convection to occur, reducing SST's influence on precipitation and surface winds. Possibly as a result of this SST dependence of ocean-to-atmospheric feedback, the SST variance peak occurs in June, when the thermocline becomes shallow but equatorial SST is still warm enough to sustain atmospheric deep convection. In November, the SST-SSH/zonal wind correlations reach a secondary maximum (Fig. 15), a month before the thermocline becomes shallowest in December (Fig. 2c). This result implies that not only the shallow thermocline but also increased mean easterly wind and the resultant upwelling are necessary to activate Bjerknes feedback: the equatorial easterlies weaken rapidly after peaking in November (Fig. 2a), dropping to their annual-mean value by December.

Although not explored in the present study, zonal temperature advection by the SEC may also play an important role. During a warm event, in response to a weakening of the equatorial easterlies, a decelerated SEC reduces the westward advection of cold water, warming the eastern equatorial ocean. Meanwhile, the mean SEC advects the warm SST anomaly to the west, inducing further air-sea interaction there. This positive feedback via advection will intensify as the mean SEC accelerates and the zonal SST gradient increases concurrently with the thermocline shoaling (Figs. 2b,c,e).

All these factors are likely to contribute to the phaselocking of the Atlantic zonal mode. Zebiak (1993) reports that individual warm/cold events tend to peak in boreal summer in his intermediate coupled model, where the thermocline depth is fixed at its annual-mean values while other mean state variables (upwelling, ocean currents, SST, and surface winds) are allowed to vary seasonally. Detailed modeling studies are necessary to examine the effect of the seasonal cycle in thermocline depth and its interaction with the other feedback mechanisms.

The mechanism proposed here does not explain ENSO seasonality in the equatorial Pacific, where the thermocline depth does not change much on the seasonal time scale. The physical processes that lead to the El Niño's phase-locking are still unclear. Possibilities include modulation of the annual cycle by the interannual displacement of the thermocline (Xie 1995), the seasonal march of major atmospheric convective zones (Harrison and Vecchi 1999), and influence from the equatorial zonal mode of the Indian Ocean (Annamalai et al. 2005).

\section{b. November easterly acceleration}

What causes the November acceleration of the equatorial easterly wind that leads to the ND seasonal cool- ing and sets the stage for the Atlantic Niño II mode? The Atlantic ITCZ stays north of the equator yearround and does not cross it except in a narrow region adjacent to South America. Therefore, the north-south seasonal migration of the marine ITCZ cannot explain why the equatorial easterly wind accelerates twice a year. Unlike the Pacific where the SST is the dominant regulator of atmospheric convection, rainfall and associated surface circulation in the Atlantic sector are affected by the continents and their interaction with the Atlantic ocean-atmosphere system (Okumura and Xie 2004; Biastti et al. 2005). Indeed, an examination of monthly climatologies suggests that a seasonal change in South American convection triggers the November easterly acceleration (Okumura 2005). The continental monsoon's effect on the equatorial North Atlantic winter trades has also been pointed out by Zhou and Lau (1998). While the easterly trades continue to intensify until January north of the equator as they suggest, the equatorial easterly winds weaken rapidly after peaking in November (Fig. 2a). We are currently investigating the seasonal cycle of convection in relation to the November intensification of easterlies on the equator, and the results will be reported elsewhere.

We have examined the simulations with three widely used atmospheric GCMs, and they do not reproduce the November acceleration of equatorial easterly winds (not shown). Its absence may partly contribute to the failure of coupled GCMs to maintain the eastern cold tongue in the Atlantic, a long-standing problem (Davey et al. 2002). The enhanced equatorial easterlies in October-November will lift the thermocline and lower SST in the east, an improvement in coupled simulations that will be further amplified by Bjerknes feedback.

\section{Summary}

Our analysis reveals several new features of tropical Atlantic climate during the little-studied period of October-January. Regarding the seasonal cycle in the equatorial Atlantic, easterly winds intensify in November, raising the thermocline in the Gulf of Guinea. While this November shoaling of the thermocline is well known in the oceanographic community, we show that it induces a noticeable SST cooling in the central equatorial Atlantic. Furthermore, this shoaling thermocline reinvigorates ocean-atmospheric interaction and the Bjerknes feedback, giving rise to the Atlantic Niño II, a hitherto unknown mode of TAV that is uncorrelated with either the Atlantic Niño in the preceding summer or the Pacific ENSO. Although the Atlantic Niño II has modest amplitude, our analysis suggests that it involves active interactions of zonal wind, up- 


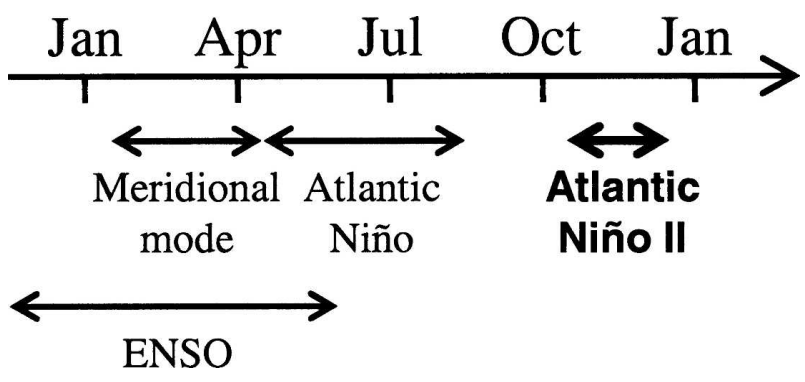

FIG. 16. Seasonality of the dominant modes of climate variability in the tropical Atlantic, modified after Sutton et al. (2000). The present study shows that the Atlantic Niño II fills an important gap in early boreal winter.

welling, thermocline depth, and SST much as in ENSO and the summer Atlantic Niño. This Atlantic Niño II mode causes interannual fluctuations in rainfall in coastal Congo-Angola during the early rainy season (ND), eventually evolving into a meridional mode in March-April that affects precipitation in semiarid northeast Brazil. Thus the Atlantic Niño II fills an important gap in the climate predictability over the Atlantic sector during $\mathrm{ND}$, a period for which little was known about modes of climate variability (Fig. 16). Triggering mechanisms and predictability of the Atlantic Niño II itself need further investigation.

Acknowledgments. This work is part of the Ph.D. dissertation of the first author, who wishes to thank J. McCreary, B. Wang, A. Timmermann, and K. Hamilton for constructive comments and suggestions. The authors would also like to thank J. Hafner for satellite data processing, P. Liu for providing atmospheric GCM data, and A. Robertson and anonymous reviewers for comments that improved the manuscript. The following datasets are obtained via FTP: AVHRR SST from the NASA Jet Propulsion Laboratory (http://podaac.jpl. nasa.gov); OISST, NCEP-NCAR reanalysis, CMAP, and COADS from the NOAA-CIRES Climate Diagnostics Center (http://www.cdc.noaa.gov); satellite altimetry product from the CLS Space Oceanography Division (http://www.cls.fr); PIRATA and ocean surface current data from the NOAA/Pacific Marine Environmental Laboratory (http://www.pmel.noaa.gov); and TRMM SST from the Remote Sensing Systems (http:// www.ssmi.com). This work is supported by the NOAA CLIVAR Program and the Japan Agency for MarineEarth Science and Technology.

\section{REFERENCES}

Adamec, D., and J. J. O'Brien, 1978: The seasonal upwelling in the Gulf of Guinea due to remote forcing. J. Phys. Oceanogr., 8, 1050-1060.
Annamalai, H., S.-P. Xie, J.-P. McCreary, and R. Murtugudde, 2005: Impact of Indian Ocean sea surface temperature on developing El Niño. J. Climate, 18, 302-319.

Armstrong, E. M., and J. Vazquez-Cuervo, 2001: A new global satellite-based sea surface temperature climatology. Geophys. Res. Lett., 28, 4199-4202.

Barreiro, M., A. Giannini, P. Chang, and R. Saravanan, 2004: On the role of the South Atlantic atmospheric circulation in tropical Atlantic variability. Earth Climate: The OceanAtmosphere Interaction, Geophys. Monogr., Vol. 147, Amer. Geophys. Union, 143-156.

Biastti, M., D. S. Battisti, and E. S. Sarachik, 2005: Terrestrial influence on the annual cycle of the Atlantic ITCZ in an AGCM coupled to a slab ocean model. J. Climate, 18, 211228

Bjerknes, J., 1969: Atmospheric teleconnections from the equatorial Pacific. Mon. Wea. Rev., 97, 163-172.

Busalacchi, A. J., and J. Picaut, 1983: Seasonal variability from a model of the tropical Atlantic Ocean. J. Phys. Oceanogr., 13, 1564-1588.

Carton, J. A., and B. Huang, 1994: Warm events in the tropical Atlantic. J. Phys. Oceanogr., 24, 888-903.

Chang, P., L. Ji, and H. Li, 1997: A decadal climate variation in the tropical Atlantic Ocean from thermodynamic air-sea interactions. Nature, 385, 516-518.

_- , and Coauthors, 2006: Climate fluctuations of tropical coupled systems-The role of ocean dynamics. J. Climate, 19, $5122-5174$.

Chiang, J. C. H., Y. Kushnir, and A. Giannini, 2002: Deconstructing Atlantic Intertropical Convergence Zone variability: Influence of the local cross-equatorial SST gradient and remote forcing from the eastern equatorial Pacific. J. Geophys. Res., 107, 4004, doi:10.1029/2000JD000307.

Davey, M. K., and Coauthors, 2002: STOIC: A study of coupled model climatology and variability in tropical ocean regions. Climate Dyn., 18, 403-420.

Ducet, N., P. Y. Le Traon, and G. Reverdin, 2000: Global high resolution mapping of ocean circulation from TOPEX/ Poseidon and ERS-1/2. J. Geophys. Res., 105, 19 477-19 498.

Enfield, D. B., and D. A. Mayer, 1997: Tropical Atlantic SST variability and its relation to El Niño-Southern Oscillation. $J$. Geophys. Res., 102, 929-945.

_ , and E. J. Alfaro, 1999: The dependence of Caribbean rainfall on the interaction of the tropical Atlantic and Pacific Oceans. J. Climate, 12, 2093-2103.

Florenchie, P., C. J. C. Reason, J. R. E. Lutjeharms, and M. Rouault, 2004: Evolution of interannual warm and cold events in the southeast Atlantic Ocean. J. Climate, 17, 23182334.

Folland, C. K., A. W. Colman, D. P. Powell, and M. K. Davey, 2001: Predictability of northeast Brazil rainfall and real-time forecast skill, 1987-98. J. Climate, 14, 1937-1958.

Foltz, G. R., S. A. Grodsky, and J. A. Carton, 2003: Seasonal mixed layer heat budget of the tropical Atlantic Ocean. $J$. Geophys. Res., 108, 3146, doi:10.1029/2002JC001584.

Giannini, A., R. Saravanan, and P. Chang, 2003: Oceanic forcing of Sahel rainfall on interannual to interdecadal time scales. Science, 14, 1027-1030.

Harrison, D. E., and G. A. Vecchi, 1999: On the termination of El Niño. Geophys. Res. Lett., 26, 1593-1596.

Hashizume, H., S.-P. Xie, W. T. Liu, and K. Takeuchi, 2001: Local and remote atmospheric response to tropical instability 
waves: A global view from space. J. Geophys. Res., 106, $10173-10186$.

Hastenrath, S., and L. Heller, 1977: Dynamics of climate hazards in northeast Brazil. Quart. J. Roy. Meteor. Soc., 103, 77-92. , and L. Greischar, 1993: Further work on the prediction of northeast Brazil rainfall anomalies. J. Climate, 6, 743-758.

Helber, R. W., R. H. Weisberg, F. Bonjean, E. S. Johnson, and G. S. Lagerloef, 2006: Satellite-derived surface current divergence in relation to tropical Atlantic SST and wind. J. Phys. Oceanogr., in press.

Hirst, A. C., and S. Hastenrath, 1983: Atmosphere-ocean mechanisms of climate anomalies in the Angola-tropical Atlantic sector. J. Phys. Oceanogr., 13, 1146-1157.

Houghton, R. W., 1983: Seasonal variations of the subsurface thermal structure in the Gulf of Guinea. J. Phys. Oceanogr., 13, 2070-2081.

Huang, B., P. S. Schopf, and Z. Pan, 2002: The ENSO effect on the tropical Atlantic variability: A regionally coupled model study. Geophys. Res. Lett., 29, 2039, doi:10.1029/ 2002 GL014872.

Jochum, M., R. Murtugudde, P. Malanotte-Rizzoli, and A. J. Busalacchi, 2004: Internal variability of the tropical Atlantic ocean. Earth Climate: The Ocean-Atmosphere Interaction, Geophys. Monogr., No. 147, Amer. Geophys. Union, 181188.

Kalnay, E., and Coauthors, 1996: The NCEP/NCAR 40-Year Reanalysis Project. Bull. Amer. Meteor. Soc., 77, 437-471.

Keenlyside, N. S., and M. Latif, 2006: Understanding equatorial Atlantic interannual variability. J. Climate, in press.

McCreary, J., J. Picaut, and D. Moore, 1984: Effects of the remote annual forcing in the eastern tropical Atlantic Ocean. J. Mar. Res., 42, 45-81.

Meehl, G. A., P. R. Gent, J. M. Arblaster, B. L. Otto-Bliesner, E. C. Brady, and A. Craig, 2001: Factors that affect the amplitude of El Niño in global coupled climate models. Climate Dyn., 17, 515-526.

Mitchell, T., and J. M. Wallace, 1992: The annual cycle in equatorial convection and sea surface temperature. J. Climate, 5, 1140-1156.

Monger, B., C. McClain, and R. Murtugudde, 1997: Seasonal phytoplankton dynamics in the eastern tropical Atlantic. J. Geophys. Res., 102, 12 389-12 411.

Moore, D., P. Hisard, J. P. McCreary, J. Merlo, J. J. O'Brien, J. Picaut, J. M. Verstraete, and C. Wunsch, 1978: Equatorial adjustment in the eastern Atlantic. Geophys. Res. Lett., 5, 637-640.

Moura, A., and J. Shukla, 1981: On the dynamics of droughts in northeast Brazil: Observations, theory and numerical experiments with a general circulation model. J. Atmos. Sci., 38, 2653-2675.

Nicholson, S. E., and D. Entekhabi, 1987: Rainfall variability in equatorial and southern Africa: Relationships with sea surface temperatures along the southwestern coast of Africa. $J$. Climate Appl. Meteor., 26, 561-578.

Nigam, S., and Y. Chao, 1996: Evolution dynamics of tropical ocean-atmosphere annual cycle variability. J. Climate, 9, 3187-3205.

Nobre, P., and J. Shukla, 1996: Variations of sea surface temperature, wind stress, and rainfall over the tropical Atlantic and South America. J. Climate, 9, 2464-2479.

Okajima, H., S.-P. Xie, and A. Numaguti, 2003: Interhemispheric coherence of tropical climate variability: Effect of the climatological ITCZ. J. Meteor. Soc. Japan, 81, 1371-1386.
Okumura, Y., 2005: Ocean-atmosphere interaction in the seasonal to decadal variations of tropical Atlantic climate. Ph.D. dissertation, University of Hawaii at Manoa, 165 pp. [Available from University Microfilms, 300 North Zeeb Rd., Ann Arbor, MI 48106.]

- and S.-P. Xie, 2004: Interaction of the Atlantic equatorial cold tongue and the African monsoon. J. Climate, 17, 35893602 .

,,-- A. Numaguti, and Y. Tanimoto, 2001: Tropical Atlantic air-sea interaction and its influence on the NAO. Geophys. Res. Lett., 28, 1507-1510.

Peter, A.-C., M. Le Hénaff, Y. du Penhoat, C. E. Menkès, F. Marin, J. Vialard, G. Caniaux, and A. Lazar, 2006: A model study of the seasonal mixed layer heat budget in the equatorial Atlantic. J. Geophys. Res., 111, C06014, doi:10.1029/ 2005JC003157.

Philander, S. G. H., 1986: Unusual conditions in the tropical Atlantic Ocean in 1984. Nature, 322, 236-238

_ and R. C. Pacanowski, 1986: A model of the seasonal cycle in the tropical Atlantic Ocean. J. Geophys. Res., 91, 14192 14206.

Picaut, J., 1983: Propagation of the seasonal upwelling in the eastern equatorial Atlantic. J. Phys. Oceanogr., 13, 18-36.

Reynolds, R. W., N. A. Rayner, T. M. Smith, D. C. Stokes, and W. Wang, 2002: An improved in situ and satellite SST analysis for climate. J. Climate, 15, 1609-1625.

Richardson, P. L., and T. K. McKee, 1984: Average seasonal variation of the Atlantic equatorial currents from historical ship drifts. J. Phys. Oceanogr., 14, 1226-1238.

Rouault, M., P. Florenchie, N. Fauchereau, and C. J. C. Reason, 2003: South East tropical Atlantic warm events and southern African rainfall. Geophys. Res. Lett., 30, 8009, doi:10.1029/ 2002GL014840.

Ruiz-Barradas, A., J. A. Carton, and S. Nigam, 2000: Structure of interannual-to-decadal climate variability in the tropical Atlantic. J. Climate, 13, 3285-3297.

Saravanan, R., and P. Chang, 2000: Interaction between tropical Atlantic variability and El Niño-Southern Oscillation. J. Climate, 13, 2177-2194.

Servain, J., A. J. Busalacchi, M. J. McPhaden, A. D. Moura, G. Reverdin, M. Vianna, and S. E. Zebiak, 1998: A Pilot Research Moored Array in the Tropical Atlantic (PIRATA). Bull. Amer. Meteor. Soc., 79, 2019-2031.

_ I. Wainer, J. P. McCreary, and A. Dessier, 1999: Relationship between the equatorial and meridional modes of climatic variability in the tropical Atlantic. Geophys. Res. Lett., 26, $485-488$.

Shannon, L. V., A. J. Boyd, G. B. Brundrit, and J. Taunton-Clark, 1986: On the existence of an El Niño type phenomenon in the Benguela system. J. Mar. Res., 44, 495-520.

Sutton, R. T., S. P. Jewson, and D. P. Rowell, 2000: The elements of climate variability in the tropical Atlantic region. $\mathrm{J}$. Climate, 13, 3261-3284.

Weisberg, R. H., and C. Colin, 1986: Equatorial Atlantic Ocean temperature and current variations during 1983 and 1984. Nature, 322, 240-243.

— tic Ocean thermocline variability. J. Phys. Oceanogr., 20, 1813-1825.

Wentz, F. J., C. Gentemann, D. Smith, and D. Chelton, 2000: Satellite measurements of sea surface temperature through clouds. Science, 288, 847-850. 
Woodruff, S. D., H. F. Diaz, J. D. Elms, and S. J. Worley, 1998: COADS release 2 data and metadata enhancements for improvements of marine surface flux fields. Phys. Chem. Earth, 23, 517-527.

Xie, P., and P. A. Arkin, 1996: Analyses of global monthly precipitation using gauge observations, satellite estimates, and numerical model predictions. J. Climate, 9, 840-858.

Xie, S.-P., 1994: On the genesis of the equatorial annual cycle. $J$. Climate, 7, 2008-2013.

- 1995: Interaction between the annual and interannual variations in the equatorial Pacific. J. Phys. Oceanogr., 25, 19301941.
—, and J. A. Carton, 2004: Tropical Atlantic variability: Patterns, mechanisms, and impacts. Earth Climate: The OceanAtmosphere Interaction, Geophys. Monogr., No. 147, Amer. Geophys. Union, 121-142.

Yamagata, T., and S. Iizuka, 1995: Simulation of the tropical thermal domes in the Atlantic: A seasonal cycle. J. Phys. Oceanogr., 25, 2129-2140.

Zebiak, S. E., 1993: Air-sea interaction in the equatorial Atlantic region. J. Climate, 6, 1567-1586.

Zhou, J., and K.-M. Lau, 1998: Does a monsoon climate exist over South America? J. Climate, 11, 1020-1040. 